\title{
Berberine modulates AP-1 activity to suppress HPV transcription and downstream signaling to induce growth arrest and apoptosis in cervical cancer cells
}

\author{
Sutapa Mahata', Alok C Bharti', Shirish Shukla', Abhishek Tyagi', Syed A Husain² and Bhudev C Das ${ }^{1,3^{*}}$
}

\begin{abstract}
Background-: Specific types of high risk Human papillomaviruses (HR-HPVs) particularly, HPV types 16 and 18 cause cervical cancer and while the two recently developed vaccines against these HPV types are prophylactic in nature, therapeutic options for treatment and management of already existing HPV infection are not available as yet. Because transcription factor, Activator Protein-1 (AP-1) plays a central role in HPV-mediated cervical carcinogenesis, we explored the possibility of its therapeutic targeting by berberine, a natural alkaloid derived from a medicinal plant species, Berberis which has been shown to possess anti-inflammatory and anti-cancer properties with no known toxicity; however, the effect of berberine against HPV has not been elucidated.

Results-: We studied the effect of berberine on HPV16-positive cervical cancer cell line, SiHa and HPV18-positive cervical cancer cell line, HeLa using electrophoretic mobility gel shift assays, western and northern blotting which showed that berberine could selectively inhibit constitutively activated AP-1 in a dose- and time-dependent manner and downregulates HPV oncogenes expression. Inhibition of AP-1 was also accompanied by changes in the composition of their DNA-binding complex. Berberine specifically downregulated expression of oncogenic cFos which was also absent in the AP-1 binding complex. Treatment with berberine resulted in repression of E6 and E7 levels and concomitant increase in p53 and Rb expression in both cell types. Berberine also suppressed expression of telomerase protein, hTERT, which translated into growth inhibition of cervical cancer cells. Interestingly, a higher concentration of berberine was found to reduce the cell viability through mitochondriamediated pathway and induce apoptosis by activating caspase-3.

Conclusion-: These results indicate that berberine can effectively target both the host and viral factors responsible for development of cervical cancer through inhibition of AP-1 and blocking viral oncoproteins E6 and E7 expression. Inhibition of AP-1 activity by berberine may be one of the mechanisms responsible for the anti-HPV effect of berberine. We propose that berberine is a potentially promising compound for the treatment of cervical cancer infected with HPV.
\end{abstract}

\section{Background}

Cervical cancer is the most frequent malignancy in Indian women, and is responsible for substantial morbidity and mortality worldwide [1]. Persistent infection with high-risk human papillomavirus (HR-HPV), most notably types 16 and 18 is an essential prerequisite for the development of cervical cancer [2]. During malignant progression, the

\footnotetext{
* Correspondence: bcdas48@hotmail.com

'Division of Molecular Oncology, Institute of Cytology and Preventive Oncology (Indian Council of Medical Research), I-7, Sector-39, Noida, Gautam Budh Nagar - 201301 India

Full list of author information is available at the end of the article
}

HPV integrates into the host cell genome resulting in a loss of expression of the viral E2 gene and over-expression of the two early viral oncogenes E6 and E7, the products of which interfere with the tumor suppressor proteins $\mathrm{p} 53$ and $\mathrm{Rb}$ respectively. E6 binds and induces ubiquitin mediated degradation of p53 while E7 inactivate pRb leading to dysregulated cell growth [3].

The constitutive expression of HR-HPV E6 and E7 oncogene is mainly dependent on the availability of host cell transcription factors. Activator protein-1(AP-1) which is a heterodimer of a group of structurally and functionally related members of the Jun proteins (c-Jun, JunB, JunD)

\section{Biomed Central}


and Fos proteins (c-Fos, FosB, Fra-1 and Fra-2) found to be constitutively active in cervical cancer. Mutational inactivation of AP-1 consensus sequence within the binding sites of the HR-HPV upstream regulatory region (URR) revealed a complete loss of transcriptional activity of the E6/E7 promoter indicating a key role of AP-1 in HPVmediated carcinogenesis [4]. Interestingly, AP-1 independently has also been shown to develop carcinogenesis in a variety of tissues [5]. Additionally, studies by our group demonstrated a significant overexpression of constitutively active AP-1 family members in cervical precancer and cancer tissues [6].

The most important risk factor in this cancer is the presence of human papillomavirus (HPV) infection. Conventional therapies like removal of lesions through cryo, laser therapy, excisional surgery, or topical application of formulations of podophyllotoxin, trichloroacetic acid and salicylic acid or 5-fluorouracil, including direct injections of interferon into the lesions may help eliminate the lesions or warts but none of them eradicates the virus. Consequently, recurrence of the lesions, as well as transmission of the virus remains a very significant problem. Since HR-HPV E6 and E7 are the two transforming proteins constantly expressed in transformed cells, they represent ideal targets for development of anti-HPV therapeutics [7]. Antiviral approach against transcriptional inactivation of HPV using herbal derivatives that show minimal or no systemic toxicity could be a promising option to control HPV infection particularly in an early stage of cervical carcinogenesis.

Berberine (5, 6-dihydro-9, 10-dimethoxybenzo[g]-1, 3-benzodioxole5,6-aquinolizum) (Figure 1) [8], a natural isoquinoline alkaloid present in roots, rhizome and outer bark of an important medicinal plant species, Berberis (B. aquifolium, B. vulgaris, B. aristata, etc.) has been reported to exhibit variety of pharmacological,

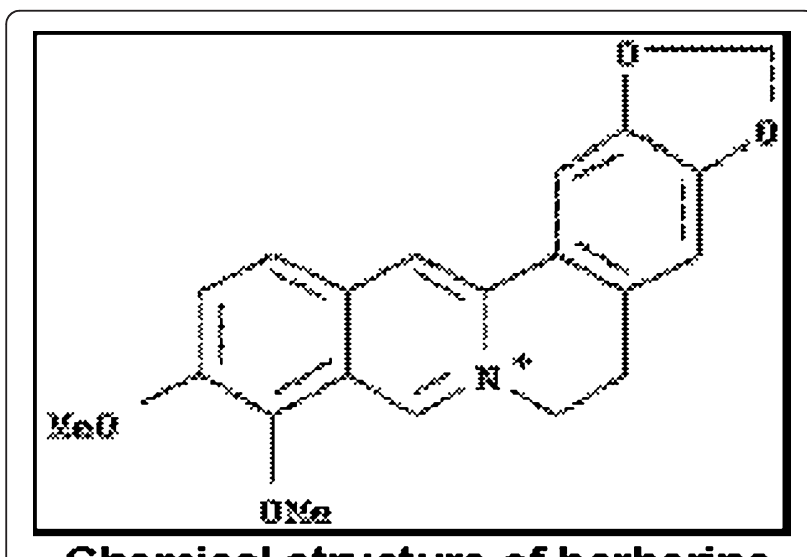

Chemical structure of berberine

Figure 1 The chemical structure of berberine. Source: British booklet on Berberine [8]. biochemical and anticancer effects [9]. The medicinal value of berberine is indicated by its use in the Indian Ayurvedic, Unani and Chinese systems of Medicine since time immemorial $[10,11]$. Berberine has been shown specifically to suppress the growth of a wide variety of tumors including leukemia [12], melanoma [13], epidermoid carcinoma [14], hepatoma [15], oral carcinoma [16] glioblastoma [17], lung [18], prostate [19] and gastric carcinoma [20] and does not have toxic effects on growth and viability of normal cells [14,19,21]. Animal studies have also shown that berberine can suppress chemical-induced carcinogenesis [22], tumor promotion [23] and tumor invasion [18,24]. It also acts as a radiosensitizer of tumor cells but not for normal cells [25]. Though anticancer activity of berberine has been demonstrated [26] but how it mediate these effects is not clearly understood and also, its effect on HPV has not been reported. Therefore, in the present study, we have investigated the effect of berberine on HPV positive cervical cancer cells to examine its anti-viral activity. We show here that both viral transcription and cellular proliferation are strongly affected by berberine which specifically suppresses HPV transcription and constitutively active AP-1 in dose and time dependent manner.

\section{Materials and methods \\ Materials}

The HPV16 positive human cervical cancer cell line, SiHa, HPV18 positive human cervical cancer cell line, HeLa and the HPV negative human cervical cancer cell line, C33a were obtained from the American Type Culture Collection (ATCC), USA and were tested and authenticated prior to initiation of experiments and periodically checked for PCR positivity of HPV16 and HPV18 and contaminations to ensure purity of the cell line. DNA hybridization probes, pHPV16 represent unit-length of HPV16 DNA [2] cloned in pBR322, pHPV18 represent unit-length of HPV18 DNA [6] cloned in pBR322, and pHF-A [6] harboring an approximately full-length insert of the fibroblast $\beta$-actin gene was kindly provided by L. Kedes (Medical Center, Palo Alto, CA). Custom synthesized and HPLC purified Oligos were procured from M/s Microsynth, (Germany); Polyclonal antibodies to AP-1, hTERT, Caspase-3, Rb, PARP-1 and Monoclonal antibodies to HPV16E6/18E6, HPV16E7, HPV18E7, p53 were purchased from Santa Cruz Biotechnology (Santa Cruz, CA). DMEM, FCS, MTT, and Penicillin-Streptomycin solution were obtained from Sigma (St Louis, MO). All other reagents were of analytical molecular biology grades.

\section{Cell culture}

Cells were maintained in Dulbecco's modified Eagle's medium (DMEM), supplemented with $10 \%$ heat- inactivated fetal calf serum and $1 \%$ penicillin/streptomycin in 
$\mathrm{CO}_{2}$ incubator with a humidified atmosphere of $95 \%$ air and $5 \% \mathrm{CO}_{2}$ at $37^{\circ} \mathrm{C}$.

\section{Berberine}

Commercially available berberine (Sigma) was freshly dissolved in DMSO [maximum concentration, $0.5 \%(\mathrm{v} / \mathrm{v})$ ], which was then added to complete cell culture medium prior to addition to subconfluent cells. Cells treated with vehicle only (DMSO, $0.5 \%$ in media) served as control.

\section{Lymphocytes isolation}

Peripheral blood lymphocytes were isolated from heparinized blood collected from healthy volunteers by standard method of Ficoll-Hypaque gradient centrifugation as described by Bharti et.al [27]. These cells were used for subsequent MTT assay.

\section{MTT assay}

The cytotoxic effects of berberine against $\mathrm{SiHa}, \mathrm{HeLa}$, C33a and Lymphocytes were determined by MTT dye uptake method. The cells were incubated in triplicate in a 96-well plate in the presence or absence of indicated test samples in a final volume of $0.1 \mathrm{ml}$ for $24 \mathrm{~h}, 48 \mathrm{~h}$ and $72 \mathrm{~h}$ at $37^{\circ} \mathrm{C}$ in a $\mathrm{CO}_{2}$ incubator. Thereafter $0.025 \mathrm{ml}$ of MTT solution $(5 \mathrm{mg} / \mathrm{ml}$ in PBS) was added to each well. After $2 \mathrm{~h}$ incubation at $37^{\circ} \mathrm{C}$, lysis buffer (20\%SDS 50\% Dimethyl Formamide) was added, and the extract was incubated overnight at $37^{\circ} \mathrm{C}$ for solublization of formazan crystals. The OD at $570 \mathrm{~nm}$ was measured using a 96-well multiscanner autoreader (Biotek, Winooski,Vermont) with the lysis buffer serving as blank. The percentage of cell viability was calculated using the following formula: Percentage cell viability $=(\mathrm{OD}$ of the experiment samples $/ \mathrm{OD}$ of the control) $\times 100$.

\section{RNA Extraction and Northern blotting}

The cellular RNA were extracted following treatment of $\mathrm{SiHa}$ and HeLa cells with 0, 50, 100 and $250 \mu \mathrm{g} / \mathrm{ml}$ berberine for $24 \mathrm{~h}$ by using TRI Reagent according to the manufacturer's instruction. The quality of RNA was estimated by electrophoresis using $2 \mu \mathrm{l}$ of RNA solution on an ethidium bromide-stained 1\% agarose gel in 3-[N-morpholino] propane-sulfonic acid (MOPS) buffer. Concentration of RNA was estimated by Nanodrop (NanoDrop Tech, USA). The probes were labeled by the random-priming method using random primer labelling kit (Genei, Bangalore, India) and northern blotting was carried out using standard protocols [28]. Briefly, approximately $15 \mu \mathrm{g}$ of RNA was resolved on 1\% agarose- MOPS formaldehyde gel. Capillary blotted Nylon membrane (IMMOBILON-NY+, Millipore, Bedford, MA) was then UV crosslinked (Hoefer UVC 500 ultraviolet crosslinker, Amersham Biosciences) and washed in 6X SSC, air dried, and finally exposed in phosphorimager (Fujifilm FLA-5100) after pre-hybridization and hybridization in Perfect HYB-PLUS (Sigma Inc, USA) solution as suggested by manufacturer's protocol.

\section{Electrophoretic mobility shift assay}

For electrophoretic mobility shift assay (EMSA), the following oligonucleotides were used: AP-1 consensus sequence 5'-CGCTTGATGACTCAGCCGGAA-3' [29], Oct-1 consensus oligonucleotide 5'-TGTCGAATGCAAATCACTAGAA-3'[30] and Sp-1 consensus sequence 5'-ATTCGATCGGGGCGGGGCGAG-3'[31]. Cells treated with different concentration of berberine for different time intervals were harvested and then nuclear extracts were prepared as described earlier [6]. The protein concentration of the extracts was measured by the spectrophotometric method using Nanodrop spectrophotometer ND-100. EMSA was performed using $10 \mu \mathrm{g}$ of nuclear extract as described previously [6]. For supershift assays, $2 \mu \mathrm{g}$ of polyclonal antibodies (Abs) directed against the Jun/Fos members (Santa Cruz Biotechnology Inc., Santa Cruz, CA) were added and the reaction mixture was further incubated for $45 \mathrm{mins}$ at $4^{\circ} \mathrm{C}$. The following antibodies were used: c-Jun (epitope corresponding to aminoterminal domain of mouse c-Jun p39); JunB (epitope corresponding to carboxy terminal domain of mouse JunB); JunD (epitope corresponding to carboxy terminus of mouse JunD); c-fos (epitope corresponding to a highly conserved domain of c-fos p62 of human origin); FosB (epitope corresponding to amino acids within the central domain of the FosB protein of mouse origin); Fra-1(epitope corresponding to amino terminus of Fra-1 of rat origin) and Fra-2 (epitope corresponding to carboxy terminus of Fra-2 of human origin). The DNA-protein complexes were then resolved on $4.5 \%$ nondenaturing polyacrylamide gel, dried and either exposed overnight to Kodak X-Omat Films (Kodak India Ltd., India) or visualized by PhosphorImager (Fujifilm FLA-5100) using Multi Gauge-ver 3.x anlaysis software. The quantitative densitometric analysis was performed using Alpha Ease FC version 4.1.0 (Alpha Innotech Corporation, IL).

\section{Western blotting}

Whole cell lysate $(50 \mu \mathrm{g} /$ lane $)$ were resolved by SDSPAGE, electrotransferred to Immobilon-P membranes (Millipore Corporation, Bedford, MA). The membrane was blocked with $10 \%$ non-fat milk and incubated overnight in PBS with 5\% milk, 0.05\% Tween-20 and probed with polyclonal rabbit primary antibodies of the corresponding family members (see Electrophoretic mobility shift assay for AP-1) at $4{ }^{\circ} \mathrm{C}$. These blots were washed, incubated with HRP- anti-rabbit IgG secondary antibodies and visualized by Luminol detection kit (Santa Cruz Biotech, USA). Membrane was re-probed for $\beta$-actin 
expression as an internal control. The ratio of the specific proteins to $\beta$-actin was calculated.

\section{Flow cytometric analysis of apoptotic cell death by Annexin V-FITC}

Cells were treated with berberine for $24 \mathrm{~h}$. The cells were then harvested, washed with PBS and incubated with AnnexinV-conjugated fluorescein isothiocynate (FITC) and propidium iodide (PI) for cellular staining as described in AnnexinV-FITC apoptosis detection kit (BD Biosciences) manufacturer's instructions. The stained cells were then analyzed by FACS. The number of 10000 events was acquired and the cells were properly gated for analysis using FACSAria instrument equipped with Flowjo software (Becton-Dickinson Biosciences, San Jose, CA).

\section{Quantitation of Caspase- 3 Activity}

The activity of caspase- 3 was measured using the active caspase-3 apoptosis kit (BD Pharmingen, USA) following the manufacturer's protocol. Briefly, cells were treated with different doses of berberine for $24 \mathrm{~h}$ or for different time intervals and were harvested by pooling attached and detached cells were pelleted with centrifugation at $200 \times g$ for $5 \mathrm{~min}$ at $4^{\circ} \mathrm{C}$. The cells were permeabilized, fixed, and stained for active caspase- 3 (PE-conjugated) as described in manufacturer's protocol (BD Biosciences).

\section{Measurement of mitochondrial membrane potential}

Cells were plated onto a $60-\mathrm{mm}$ tissue culture plate at subconfluent density. After $24 \mathrm{~h}$ incubation cells were exposed to different doses of berberine and incubated with $5 \mu \mathrm{M} \mathrm{JC}-1$ fluorescence dye for $30 \mathrm{~min}$ in $\mathrm{CO}_{2}$ incubator and washed several times with $\mathrm{PBS}$ pre-warmed at $37^{\circ} \mathrm{C}$. Mitochondrial membrane potential was evaluated qualitatively under a fluorescence microscope (Olympus IX81) using $568 \mathrm{~nm}$ filter.

\section{Statistical analysis}

All experiments were conducted in triplicate for at least three times. The statistical significance of difference between control and treated groups was analyzed by the one- way ANOVA (Holm-Sidak method) (Sigma Stat 3.5, Systat software Inc., CA). The difference was considered significant when the $p$ value was less than 0.05 .

\section{Results}

Berberine selectively downregulates constitutively active AP-1 in HPV16 positive cervical cancer cells, $\mathrm{SiHa}$

To assess anti-HPV activity of berberine, we investigated the effect of berberine on AP-1, which is constitutively active in cervical cancer and plays an indispensable role in transcriptional regulation of HPV oncogenes. HPV16 positive cervical carcinoma cells, $\mathrm{SiHa}$ were treated with different concentrations of berberine for $24 \mathrm{~h}$ and the nuclear protein $(10 \mu \mathrm{g})$ extracted were examined for AP-1 DNA-binding activity by EMSA. Results revealed a dose-dependent decrease of AP-1 DNA binding activity in berberine-treated cells (Figure 2A). Inhibition was apparent at $50 \mu \mathrm{g} / \mathrm{ml}$ and a maximum inhibition was obtained at $250 \mu \mathrm{g} / \mathrm{ml}$. Densitometric analysis of the retarded bands showed a 10 fold decrease in AP-1 DNAbinding activity. Further analysis of time kinetics of berberine-induced AP-1 inhibition for different time periods revealed a reduced AP-1 DNA binding activity by $12 \mathrm{~h}$ which declined further and disappeared by $24 \mathrm{~h}$ (Figure 2B). Specificity of AP-1 DNA binding was confirmed by cold competition assay using 100 fold molar excess of a homologous (AP-1) probe which resulted in disappearance of retarded complex whereas it remained unaffected by addition of heterologous (Oct-1) probe (Figure 2C). Similarly, effect of berberine on general transcription was checked by examining nuclear protein $(10 \mu \mathrm{g})$ of berberine-treated cells for binding to Sp1, a transcription factor that is ubiquitously active in majority of cells (Figure 2D). Results showed no inhibitory effect of berberine on Sp1 DNA binding activity. The results, thus establish that berberine selectively suppresses constitutively active AP1 in a dose and time-dependent manner in cervical cancer cells.

\section{Berberine alters the heterodimerization pattern of AP-1 and differentially modulates expression of Jun and Fos family proteins}

To determine the effect of berberine on composition of AP-1 complex and to dissect out the AP-1 protein most sensitive to berberine treatment, we performed supershift assays on $\mathrm{SiHa}$ nuclear proteins treated with berberine $(250 \mu \mathrm{g} / \mathrm{ml})$ for 8,12 and $18 \mathrm{~h}$. Under normal conditions, AP-1 consists of c-Fos, JunB, and JunD (Figure 2E) in its active DNA-binding complex and over $60 \%$ of the supershifted band was formed by c-Fos only, while other two members, JunB, and JunD, contributed moderately, but other Fos family members (FosB, Fra-1, Fra-2) as well as c-Jun did not participate in active AP-1 complex. Interestingly, nuclear protein extracted from berberine treated $\mathrm{SiHa}$ cells after $12 \mathrm{~h}$ displayed exclusive involvement of JunB in the binding activity $(\sim 70 \%)$ with no involvement of either JunD/c-Jun or any of c-Fos family members in active AP-1 complex (Figure 2E). These results suggest that berberine-induced AP-1 inhibition is primarily mediated through exclusion of c-Fos family of proteins and JunD from active AP-1 complex whereas JunB DNA appears to form homodimer.

In order to assess the possibility of decreased involvement of c-Fos and JunD in active AP-1 complex could be due to their reduced expression, we analyzed expression 


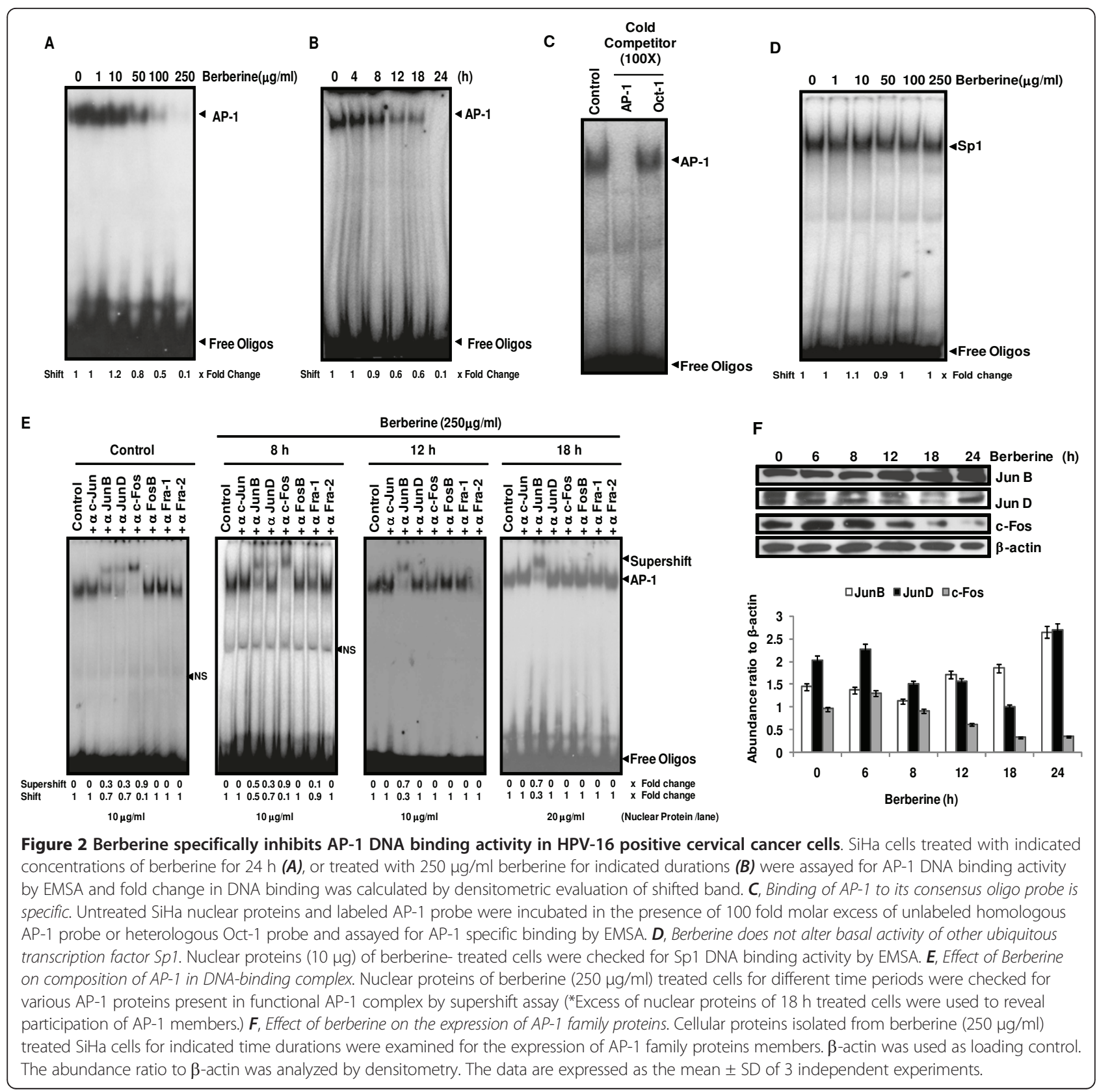

of c-Fos, JunB, and JunD by western blotting at different time intervals following berberine treatment. As shown in Figure 2F, berberine-treated cells demonstrated reduced expression of c-Fos but interestingly though JunD also showed reduced expression by $12 \mathrm{~h}$ of treatment, its expression got recovered by $24 \mathrm{~h}$. On the other hand, a compensatory and marginal increase in the expression of JunB was observed in berberine-treated cells. These results, therefore, indicate berberine-induced inhibition of AP-1 is primarily mediated through inhibition of c-Fos expression and its exclusion from active complex in cervical cancer cells.
Berberine inhibits AP-1 activity and reduces the expression of c-Jun and c-Fos in HPV18 positive cervical cancer cells

We further looked into the effect of berberine on AP-1 activity in cervical cancer cells, HeLa that harbor HRHPV18 infection and also express constitutively active AP-1. Nuclear proteins of HeLa cells which were treated with varying concentrations of berberine demonstrated a similar specific dose-dependent inhibition of AP-1 DNA binding by EMSA (Figure 3A, B). HeLa cell nuclear proteins were also examined for the composition of activated AP-1 complex by supershift assays revealed presence of 


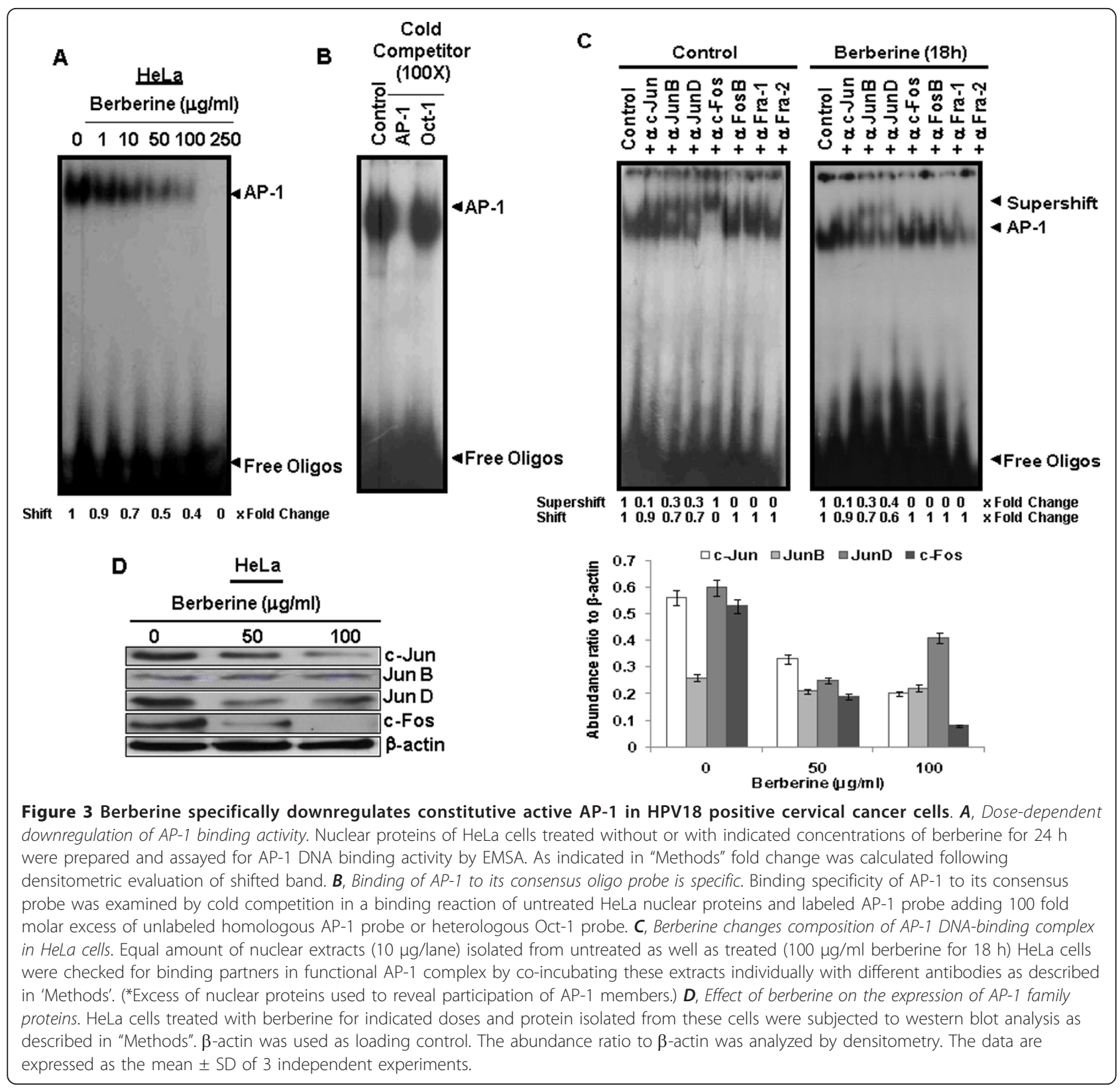

c-Jun, JunB, JunD and c-Fos (Figure 3C) in active AP-1 complex whereas FosB, Fra-1, and Fra-2 showed no participation in the AP-1 complex formation. As compared to $\mathrm{SiHa}$ cells, where there is no involvement of c-Jun, we have found presence of c-Jun in HeLa cells but to a lesser extent. To determine the effect of berberine on specific AP-1 proteins involved in active complex, nuclear protein of HeLa cells treated with berberine were examined by supershift assays which displayed exclusive involvement of JunB and JunD in the binding activity with no involvement of c-Fos (Figure $3 \mathrm{C}$ ). These results suggest that cFos is the most sensitive AP-1 member and its exclusion from active AP-1 complex contributes maximally to the loss of AP-1 activity in berberine-treated cells. Further investigation of AP-1 protein expression revealed a dosedependent loss of c-Fos and c-Jun in berberine treated cell (Figure 3D). These observations collectively indicated exclusion of Fos member from active complex and loss of AP-1 activity are primarily mediated through loss of expression of c-Fos and c-Jun in berberine-treated cells.

Berberine downregulates HPV16 and HPV18 transcription, suppressed E6, E7 and hTERT expression and increased p53 and Rb expression in cervical cancer cells

To investigate, whether inhibition of AP-1 by berberine has any impact on the viral transcription, total RNA was 
extracted from the $\mathrm{SiHa}$ and HeLa cells following treatment with different concentrations of berberine for $24 \mathrm{~h}$ and northern blotting was performed using HPV16DNA and HPV18-DNA probes respectively. The results revealed a concentration dependent decline in HPV16specific transcripts in berberine-treated $\mathrm{SiHa}$ cells (Figure 4A). Berberine at $50 \mu \mathrm{g} / \mathrm{ml}$ was found to significantly downregulate viral transcription and strongest reduction was detected in cells treated with $250 \mu \mathrm{g} / \mathrm{ml}$. A decline in HPV18-specific transcripts was also observed in berberine-treated HeLa cells (Figure 4A). Suppression of HPV transcription was found to be selective since expression of house keeping gene, $\beta$-actin was not affected in both the cells.

We then proceeded to investigate the expression level of HPV oncogenes, E6 and E7 after berberine treatment. Data from western blotting analysis showed that the expression of HPV16E6, HPV16E7, HPV18E6 and HPV18E7 were significantly suppressed by berberine in cervical cancer cells in a dose-dependent manner (Figure 4B).

The two most essential cell cycle regulators and tumor suppressor proteins, p53 and Rb being the targets of highrisk HPV E6 and E7 oncoproteins respectively, we also examined the status of p53 and $\mathrm{Rb}$ expression in $\mathrm{SiHa}$ and HeLa cells. Both of these cervical cancer cells expressed p53 and $\mathrm{Rb}$ at low levels which showed a dose- dependent increase in expression following treatment with berberine (Figure 4C).

Since two viral oncoproteins, E6 and E7 encoded by HR-HPVs contribute to immortalization of primary human epithelial cells through the induction of telomerase activity by stimulating transcription of the catalytic subunit of telomerase, hTERT, we examined whether suppression of HPV transcription and reduced expression of viral oncogenes due to berberine also result in altered expression of hTERT. Cellular proteins $(50 \mu \mathrm{g})$ extracted from $\mathrm{SiHa}$ and HeLa cells were incubated in the absence or presence of berberine $(100 \mu \mathrm{g} / \mathrm{ml}$ for $24 \mathrm{~h})$ was checked for hTERT expression using western blotting. As depicted in Figure 4D, high expression of hTERT protein was observed in untreated cells which decreased significantly upon berberine treatment in both the cells.

\section{Berberine decreases cell viability and induce growth inhibition in cervical cancer cells}

Activation of AP-1 along with increased expression of viral oncoproteins and telomerase are all critical prerequisites for growth promoting and cell survival mechanisms of cervical cancer cells. Therefore, we were interested to check how does inhibition of these factors translates onto cell survival and growth of berberine-treated cells. For this, cells were treated with different concentration of berberine for $24 \mathrm{~h}$ and their viability was checked by MTT assay. As indicated in Figure 5A, Treatment of berberine with varying concentration resulted in concentration-dependent loss of cell viability of both $\mathrm{SiHa}$ and HeLa cells with $50 \%$ inhibitory dose $\left(\mathrm{ID}_{50}\right.$ ) of approximately $90 \mu \mathrm{g} / \mathrm{ml}$ for $\mathrm{SiHa}$ and $75 \mu \mathrm{g} / \mathrm{ml}$ for HeLa cells and maximal effect was observed at $250 \mu \mathrm{g} / \mathrm{ml}$. SiHa cells were also checked for their growth kinetics at 24, 48 and $72 \mathrm{~h}$ in the absence or presence of different concentration of berberine. As summarized in SiHa cell growth curves in the presence of berberine (Figure 5B), berberine at as low as $10 \mu \mathrm{g} / \mathrm{ml}$ could retard the growth of cervical cancer cells. Berberine at concentration higher than $50 \mu \mathrm{g} / \mathrm{ml}$ resulted in reduced cell viability drastically and cultures did not recover within $72 \mathrm{~h}$. Though berberine inhibits cell proliferation of HPV positive cervical cancer cells, however, in case of HPV negative cervical cancer C33a cells we did not find significant inhibitory effect of berberine on cell viability (1-24\% inhibition) (Figure 5A). Treatment of lymphocytes with berberine also results in a non significant inhibitory effect on cell viability (1-4\%) at the higher concentrations of berberine $(100 \mu \mathrm{g} / \mathrm{ml}$ and $250 \mu \mathrm{g} / \mathrm{ml})$ after $24 \mathrm{~h}$ of treatment (Figure 5A). These data indicates that berberine has a better cytotoxic effect on HPV positive human cervical cancer cells.

\section{Berberine-induced growth inhibition is mediated through induction of apoptosis}

To understand the mechanism of berberine-induced growth inhibition and to examine whether berberineinduced inhibition of cervical cancer cells was associated with the induction of apoptosis, $\mathrm{SiHa}$ and HeLa cells were treated with berberine and berberine-induced apoptosis was assessed using Annexin V-PI staining of the treated cells that identify specifically the cells undergoing apoptotic cell death and start expressing phosphatidylserine on their cell surface. As shown in Figure 6A, cells treated with berberine had a very high Annexin $\mathrm{V}$ staining and were also positive for PI, a phenotype generally expressed by early apoptotic cells when compared to untreated cells.

To further dissect the berberine-induced apoptotic mechanism, we checked the effect of berberine on Poly (ADP-ribose) polymerase (PARP-1) cleavage, the downstream substrate of active caspase 3 . Berberine-treated whole cell lysates $(50 \mu \mathrm{g})$ of $\mathrm{SiHa}$ and HeLa cells were probed for the analysis of PARP-1 by western blotting which showed cleavage of $116 \mathrm{kDa}$ intact PARP-1 into $85 \mathrm{kDa}$ fragment in both the cells (Figure 6B). The quantitation of cells for active caspase 3 by flow cytometry revealed $70 \%$ cells positive by $24 \mathrm{~h}$ when treated with $100 \mu \mathrm{g} / \mathrm{ml}$ berberine and almost all cells had active caspase-3 when treated with $250 \mu \mathrm{g} / \mathrm{ml}$ of berberine in $\mathrm{SiHa}$ cells (Figure 6C). About 99\% cells were positive for active caspase-3 in HeLa cells treated with $100 \mu \mathrm{g} / \mathrm{ml}$ berberine for $24 \mathrm{~h}$ (Figure 6C). 


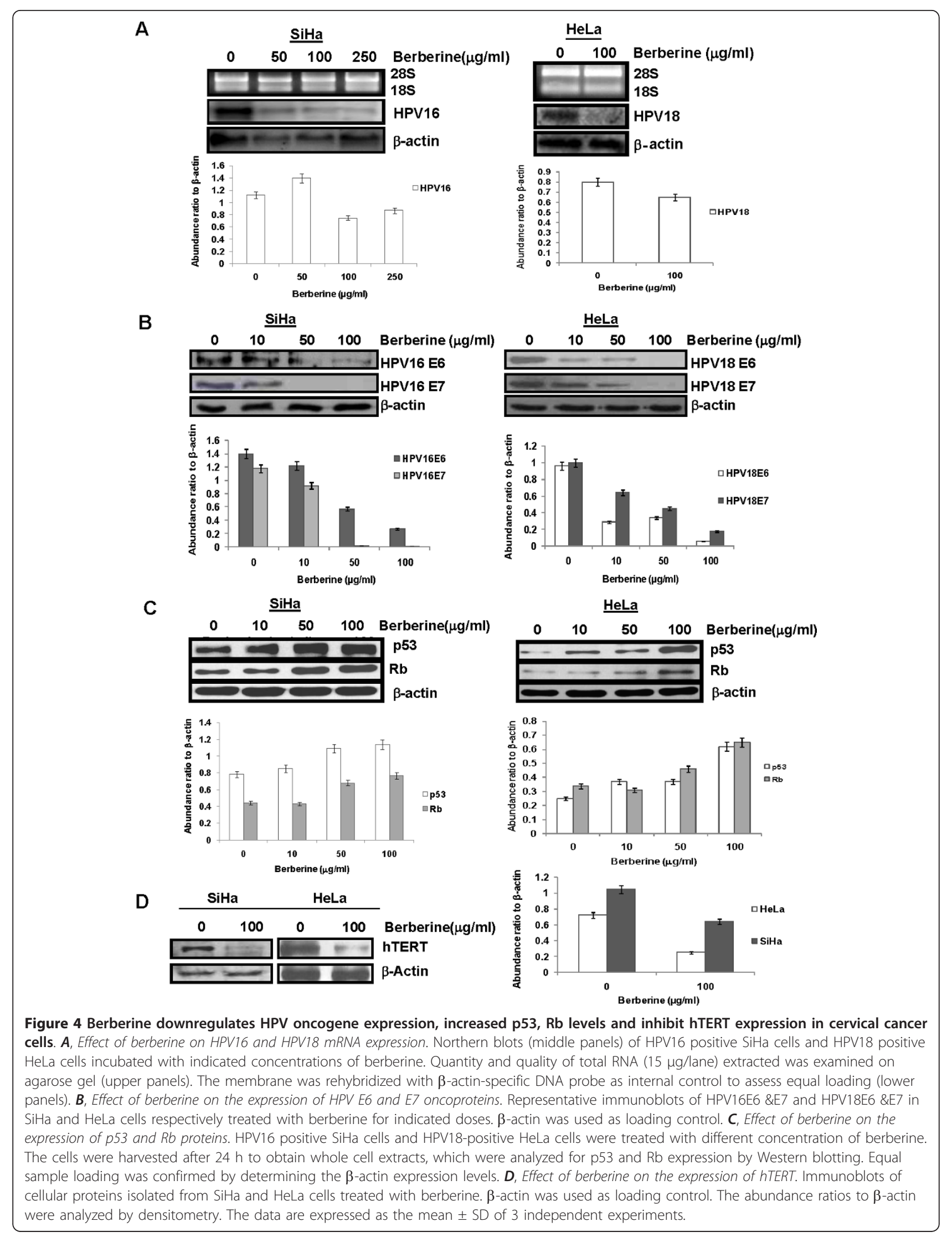


A

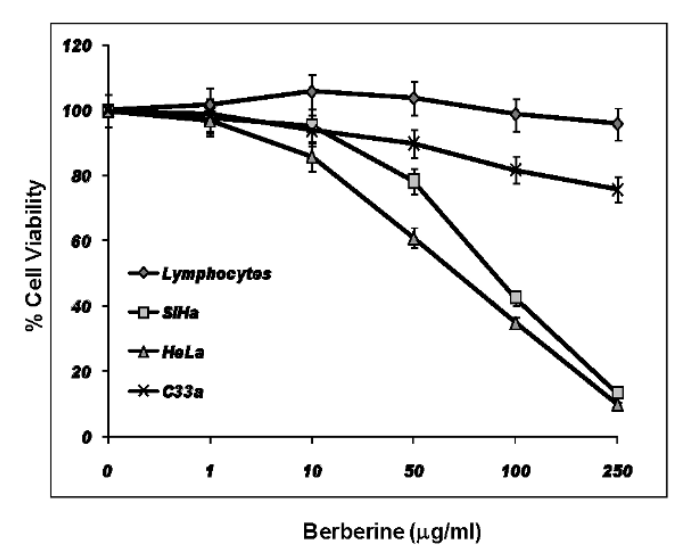

B

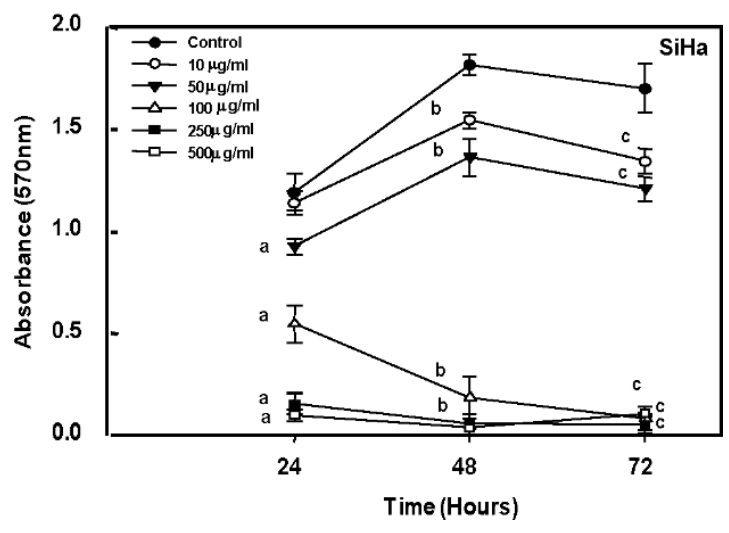

Figure 5 Berberine treatment results in dose-dependent loss of cell viability and induces growth inhibition in cervical cancer cells. A, Percent cell viability of cells treated with berberine for $24 \mathrm{~h}$. Cervical cancer cells and normal peripheral blood lymphocytes were treated with indicated doses of berberine in triplicates and the viability was measured at different time intervals by MTT assay as described in "Methods". B, Growth curve of berberine-treated SiHa cells at different time points reflecting cytotoxic and cytostatic effects at different concentration. Error bars indicates SD. ${ }^{a} p-<0.001$ is compared to untreated control at $24 \mathrm{~h},{ }^{b} p-<0.001$ is compared to untreated control at $48 \mathrm{~h},{ }^{c} p$ - $<0.001$ is compared to untreated control at $72 \mathrm{~h}$

Since loss of mitochondrial membrane potential is the primary target for majority of extrinsic apoptotic signals, we checked the integrity of mitochondrial membrane using metachromatic dye, 5,5'6,6' tetrachloro-1,1'3,3' tetraethylbenzimidazolylc iodide (JC-1), which stains the mitochondria red when their membranes are intact (polarized) whereas they give green fluorescence with depolarized membranes. Figure 6D clearly demonstrates that in cells treated with a high concentration of berberine (Figure 6D, bottom panels) mitochondria lost their membrane potential and thus proceeded through apoptosis.

\section{Discussion}

Host cell derived transcription factor, AP-1 binds to long control region or upstream regulatory region (URR) of $\mathrm{HPV}$, plays an essential role in HPV-mediated host cell immortalization and oncogenic transformation. Sitedirected mutagenesis of AP-1 binding sites within the URR regions [32] and stable infection assays in raft culture [33] have established an indispensible role of AP-1 in initiating and maintaining the expression of two essential high risk HPV oncoproteins E6 and E7 during cervical carcinogenesis. Earlier studies from our group and others have demonstrated overexpression and constitutive activation of AP- 1 in cervical cancer cells and the DNA binding affinity of AP-1, as well as the expression of its constituent members, varies as a function of the severity of cervical lesions [6,34]. Thus transcription factor, AP-1 can be considered as potential therapeutic targets for cervical cancer. In the present investigation, we show that a naturally occurring isoquinoline alkaloid, berberine, selectively suppress expression of AP-1 transcription factor in a dose and time dependent manner. Inhibition of AP-1 was accompanied by suppression of HPV transcription and oncogene expression as well as inhibition of downstream telomerase component, hTERT. Berberine-mediated inhibition of growth promoting signals culminated in growth inhibition and loss of cell viability through induction of apoptosis in cervical cancer cells. Our results demonstrated a dose-dependent selective suppression of AP-1 activity by berberine which was accompanied by suppression of c-Fos and JunD expression and their reduced involvement in functional AP-1 complex in HPV positive cervical cancer cells irrespective of infecting HR-HPV types whereas JunB that also participated in an active AP-1 complex remained unaffected. Comparison between the two cell lines revealed a specific effect of berberine on c-Fos and c-Jun resulting in their exclusion from the functional AP-1 complex which could be partly due to downregulation of their respective expression levels. Earlier studies also described berberine-induced inhibition of AP-1 in murine tumor models as well as hepatic, breast and oral cancer cells $[16,24,35]$, but the mechanism of its inhibition remained unclear. Recent study shows that inhibitory effect of berberine could be mediated through inhibition of c-Jun that suppresses expression of downstream gene, cyclin D1 and results in cell cycle arrest [36]. However, in HPV16 positive SiHa cells or HPV18 positive HeLa cells it appears that berberine is not executing its effect through this mechanism as involvement of c-Jun in active AP-1 is negligible [6]. On the contrary, expression of c-Fos which is the major partner of active AP-1 dimer was the target of berberine and was found to be the most sensitive among all AP-1 proteins. Although further 


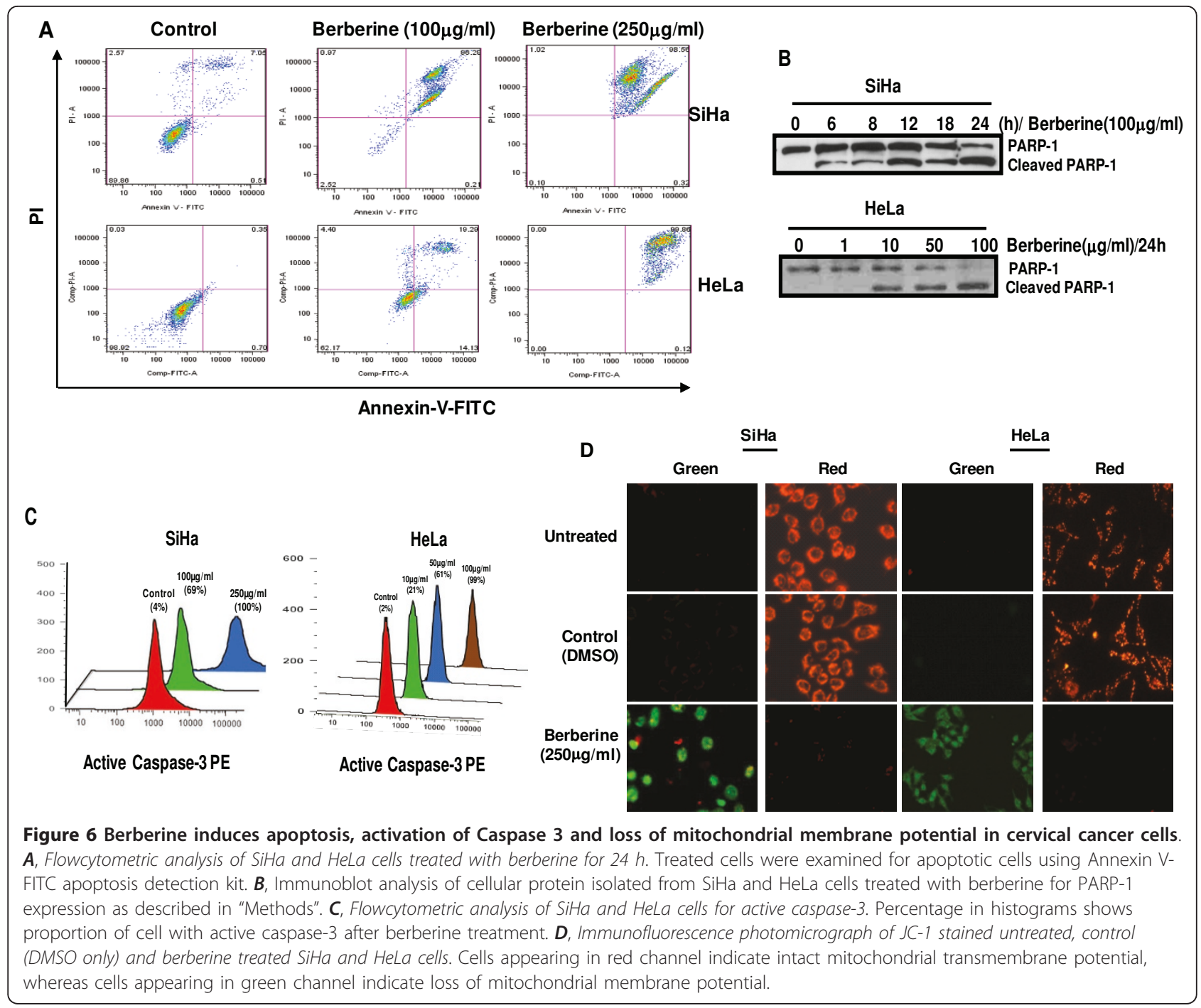

experiments using selective inhibition of c-fos and JunD by specific siRNA or reporter assays comparing the different homodimers and heterodimers of Jun and Fos family members are required to validate the significance of altered AP-1 composition, the present observations do support berberine as a preferred anti-HPV therapeutic molecule for cervical carcinogenesis. Rapidly growing amount of data from experimental, clinical and animal studies reveal that c-Fos appears to have strong oncogenic activity and is frequently overexpressed in almost all tumor cells [5]. Our earlier study demonstrated c-Fos as a major AP-1 member which showed high expression in cervical carcinogenesis [6]. In an ingenious experiment where c-Fos was ectopically over expressed through stable transfection of nontumorigenic HeLa-fibroblast hybrid 444 cells, it induced tumorigenity. This reiterates the tumorigenic role of c-Fos [37]. AP-1 has been shown to be an important target for anti-oxidant mediated action on cervical cancer cells [28]. However, the mechanism of their action may differ as antioxidants like PDTC enhances AP-1 binding and elicits up-regulation of c-Fos and c-Jun expression. Instead of acting directly on c-Fos it results in upregulation of Fra-1 which has antagonistic role to c-Fos and prevents its involvement in formation of functional AP-1 complex [28]. Though the mechanism(s) underlying berberine-induced inhibition of c-Fos expression is unclear, studies on vascular smooth muscle cells demonstrated that berberine can inhibit cFos expression by inhibiting ERK1/2 $[38,39]$, the upstream kinases responsible for c-Fos expression through transcription factor TCF/Elk-1 [40].

The gradual but distinct increase in JunB protein expression after berberine treatment strongly support the tumor suppressor activity of JunB as it was earlier reported that JunB and JunD can negatively regulate cell proliferation [41] and has an opposite effect on gene 
expression. Furthermore, JunB is also known to be a weaker transactivator than C-Jun [42]. Though JunB is essential for the HPV18 P105 promoter activation [32], there may be possibility that interaction with other proteins may inhibit DNA binding due to direct protein-protein interaction [43] thus, negative interference between proteins, either c-Jun or JunD may be one of the reasons of decrease in AP-1 DNA binding activity.

Our results indicate that berberine can effectively suppress HPV transcription and thus could inhibit the expression of its two oncogenes, E6 and E7 that are critically involved in cellular transformation. Spatial and temporal expression of these viral genes is tightly controlled by specific cognate sequences in URR that bind specific transcription factors of the host cells. The sequence analysis of viral URR region which controls the expression of these oncogenes demonstrates presence of multiple AP-1 binding sites [44] and thus indicates a direct involvement of this transcription factor in oncogenic transformation. Suppression of HPV transcription by berberine, therefore, could be the direct outcome of inhibited AP-1 activation in cervical cancer cells. Apart from targeting p53 and pRB, E6 and E7 have been demonstrated to induce transcription of hTERT, the active component of telomerase responsible for its catalytic activity [45]. Berberine-induced inhibition of viral transcription was associated with suppressed hTERT expression; hence berberine could also target telomerase activity in cervical cancer cells, which we have shown earlier to be an important marker for cervical carcinogenesis [46]. Earlier study on human leukemia cells also provided the evidence that berberine could inhibit telomerase by directly inhibiting expression of its components nucleophosmin/B23 [47] and thus could effectively suppress overall activity independent of HPV involvement. Collectively these observations indicate that berberine could effectively target survival advantage rendered by telomerase expression in HPVinfected cervical cancer cells and could suppress cell proliferation.

In addition to its inhibitory effects on HPV transcription, berberine also antagonizes cell proliferation. Our results demonstrate two distinct concentration-dependent growth inhibitory effects of berberine on cervical cancer cells. Berberine at $50 \mu \mathrm{g} / \mathrm{ml}$ or lower suppressed proliferation whereas at concentration higher than 50 $\mu \mathrm{g} / \mathrm{ml}$ resulted in dose-dependent apoptosis. Similar concentration-dependent biphasic effects have been reported earlier [48]. Similar to the cytotoxic/cytostatic effect of berberine observed in present investigation especially in cancer cell lines in contrast to normal lymphocytes, a comparative analysis of studies performed on various human cancer cell lines and primary cultures using purified berberine revealed a differential sensitivity of various cancer cell types whereas normal cells remained unaffected (Table 1). Interestingly, majority of studies performed on cervical cancer cells showed requirement of high concentration of berberine for manifestation of its cytotoxic effect $[26,49,50]$ which could be ascribed to viral etiology of cervical cancer and overexpression of viral oncoproteins E6 and E7 that may effectively override cellular checkpoints. However, it was also observed that the effective cytotoxic doses were always less in HPV positive cells as compared to HPV negative cervical cancer cell, C33a that have undergone cellular transformation independent of viral infection. The reason for such a dichotomy in berberine's effect in cervical cancer cells is unclear.

The anti-proliferative and apoptotic activity of berberine have been attributed to its concentration-dependent selective accumulation in mitochondria at lower concentration and nuclear as well as cytoplasmic accumulation at higher mitochondria-saturating doses that could interfere with DNA synthesis, perturb cell cycle and sufficient to trigger apoptosis. Our long term cultures of berberine-treated cells also demonstrated a suppressed growth at low doses without any prominent cell death component. Since berberine is a substrate of ATP-driven drug efflux pump [51], it is likely that at saturating concentrations berberine reduces the energy levels of the mitochondria below critical levels resulting in triggering of programmed cell death. This assumption gets strength from the experiments showing berberine effectively synergizes with drug efflux pump inhibitors [52]. Some investigators propose berberine's DNA-binding activity[53] could be responsible for rapid inhibition of DNA synthesis of berberine-treated cells and cell cycle arrest in S phase and G2/M phase [20]. Apart from these direct actions of berberine its inhibitory action on viral oncoproteins (E6/E7) expression via inhibition of AP-1 could be primarily responsible for growth suppression and induction of apoptosis in HPV positive cervical cancer cells. Our observations together with confirmatory annexin $\mathrm{V}$ analysis, suggest berberine could antagonize multiple survival and growth promoting mechanisms operating in cervical cancer cells and can induce apoptosis in a dose-dependent manner.

The key biochemical event involved in the induction of apoptosis is activation of caspase 3 which is mediated through proteolytic cleavage of procaspase3 via upstream caspases (caspase7/9 or caspase 8). Berberine-treated cells demonstrated activation of caspase 3 which also corroborated with proteolytic cleavage of its substrate PARP-1 as early as 6 hours. These apoptotic events were found associated with loss of mitochondrial membrane potential which is the primary mechanism of action of many chemotherapeutic/chemopreventive agents as well as other external apoptotic stimuli [54]. This event is sufficient to release cytochrome $\mathrm{C}$ from mitochondrial 
Table 1 Comparative analysis of in vitro studies performed for assessing anti-cancer properties of purified berberine $(>99 \%)$ in various human cancer and normal cells

\begin{tabular}{|c|c|c|c|c|c|c|}
\hline \multirow[t]{2}{*}{ Cells Type (Human) } & \multirow[t]{2}{*}{ Cell Line } & \multicolumn{2}{|c|}{$\begin{array}{l}\text { Concentration Range } \\
\text { Tested }\end{array}$} & \multirow[t]{2}{*}{$\begin{array}{l}\text { Percent Cell Death at max. Dose after } 24 \\
\text { h (Approx; \%) }\end{array}$} & \multirow[t]{2}{*}{$\begin{array}{l}\mathrm{IC}_{50}(\mu \mathrm{g} / \mathrm{ml}) \\
\text { after } 24 \mathrm{~h}\end{array}$} & \multirow[t]{2}{*}{ Reference } \\
\hline & & $\mu \mathrm{M}$ & $\mu \mathrm{g} / \mathrm{ml}$ & & & \\
\hline $\begin{array}{l}\text { Tongue squamous } \\
\text { carcinoma }\end{array}$ & SCC-4 & $15-100$ & $5.58-37$ & 45 & $28(48$ h) & {$[55]$} \\
\hline \multirow[t]{5}{*}{ Prostrate carcinoma } & LNCaP & $10-100$ & $3.7-37$ & 35 & $>37$ & [19] \\
\hline & & $5-100$ & $1.8-37$ & 65 & 22.3 & {$[56]$} \\
\hline & DU145 & $10-100$ & $3.7-37$ & 40 & $>37$ & [19] \\
\hline & PC-3 & 10- 100 & $3.7-37$ & 70 & 18.6 & [19] \\
\hline & & $5-100$ & $1.8-37$ & 50 & 37 & {$[56]$} \\
\hline $\begin{array}{l}\text { Oral squamous cell } \\
\text { carcinoma }\end{array}$ & HSC-3 & $5-75$ & $1.8-28$ & 82 & 6.7 & {$[57]$} \\
\hline \multirow{2}{*}{$\begin{array}{l}\text { Non-small cell lung } \\
\text { carcinoma }\end{array}$} & A549 & $25-100$ & $9.3-37$ & 55 & 28 & [21] \\
\hline & H1299 & $25-100$ & $9.3-37$ & 50 (48 h) & 37 (48 h) & [21] \\
\hline $\begin{array}{l}\text { Nasopharyngeal } \\
\text { carcinoma }\end{array}$ & $5-8 \mathrm{~F}$ & $2.5-100$ & $0.93-37$ & 50 & 37 & {$[58]$} \\
\hline Leukemia & HL-60 & $5-60$ & $1.8-22$ & 70 & $<11$ & [59] \\
\hline \multirow[t]{6}{*}{ Hepatoma } & KIM-1 & $0.01-100$ & $0.0037-37$ & 35 & 14.88 & {$[35]$} \\
\hline & Нер3В & $0.32-320$ & $0.119-119$ & 8.5 & Not defined & {$[60]$} \\
\hline & HA22T/VGH & $0.32-320$ & $0.119-119$ & 1 & Not defined & {$[60]$} \\
\hline & HepG2 & $28-107$ & $10-40$ & 95 & $13(48 \mathrm{~h})$ & [61] \\
\hline & & $1-10$ & $0.37-3.7$ & 70 & 0.52 & {$[62]$} \\
\hline & & $0.32-320$ & $0.119-119$ & 6 & ND & {$[60]$} \\
\hline \multirow[t]{2}{*}{ Glioma } & U87 & $1-20$ & $1-7.4$ & 40 & $>7.4$ & {$[63]$} \\
\hline & T98G & $134-538$ & $50-200$ & 60 & 134 & {$[17]$} \\
\hline Gastric carcinoma & SNU-5 & $50-200$ & $18.6-74$ & 95 & 17.85 & {$[20]$} \\
\hline Embryonic kidney & HEK-293T & $1-10$ & $0.37-3.7$ & 35 & 5 & {$[62]$} \\
\hline Epidermoid carcinoma & A431 & $5-75$ & $1.8-28$ & 45 & $>28$ & [14] \\
\hline Breast carcinoma & MDA-MB-231 & $1-10$ & $1-3.7$ & 0 & Not defined & [24] \\
\hline \multirow[t]{8}{*}{ Cervical carcinoma } & C33a (HPV-) & $2.7-672$ & $1-250$ & 24 & $>250$ & $\begin{array}{l}\text { Current } \\
\text { study }\end{array}$ \\
\hline & CaSki (HPV16+) & $50-150$ & $18.6-55.8$ & 80 & 42 & {$[26]$} \\
\hline & SiHa (HPV16+) & $2.7-672$ & $1-250$ & 87 & 90 & $\begin{array}{l}\text { Current } \\
\text { study }\end{array}$ \\
\hline & HeLa (HPV18+) & $0.27-403$ & $0.1-150$ & ND & 6 & [49] \\
\hline & & $0.1-10$ & $0.037-3.7$ & No effect & Not defined & {$[64]$} \\
\hline & & $33.5-269$ & $12.5-100$ & 50 & 100 & {$[50]$} \\
\hline & & $1-10$ & $0.37-3.7$ & 48 & 4 & [62] \\
\hline & & $2.7-672$ & $1-250$ & 90 & 75 & $\begin{array}{l}\text { Current } \\
\text { study }\end{array}$ \\
\hline \multirow[t]{5}{*}{ Normal Cells } & $\begin{array}{l}\text { Bronchial } \\
\text { epithelium }\end{array}$ & $25-100$ & $9.3-37$ & 5 & No effect & [21] \\
\hline & Lymphocytes & $2.7-672$ & $1-250$ & 4 & No effect & $\begin{array}{l}\text { Current } \\
\text { study }\end{array}$ \\
\hline & $\begin{array}{l}\text { Prostrate } \\
\text { epithelium } \\
\text { (PWR-1E) }\end{array}$ & $5-100$ & $1.8-37$ & 40 & Not defined & [56] \\
\hline & & $10-100$ & $3.7-37$ & 5 & No effect & [19] \\
\hline & $\begin{array}{l}\text { Epidermal } \\
\text { keratinocytes }\end{array}$ & $5-75$ & $1.8-28$ & $11(48 \mathrm{~h})$ & No effect & [14] \\
\hline
\end{tabular}


membrane and execute proteolytic activation of caspases. Nonetheless, direct mitochondrial tropism of berberine through induction of GADD153 levels [26] could also have directly contributed to the loss of mitochondrial potential. Though there could be multiple direct or indirect mechanisms, these observations collectively indicate a potential role of mitochondria in berberine-induced apoptosis.

\section{Conclusions}

In view of potential anti-HPV activity displayed by berberine through inhibition of constitutively active AP-1 as well as its selective, anti-proliferation and cytotoxic effects coupled with pharmacological safety in human, berberine appears to be a promising therapeutic agent for the treatment of cervical cancers.

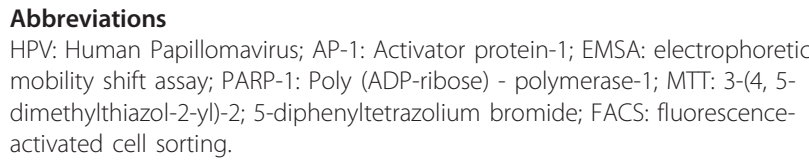

Abbreviations

HPV: Human Papillomavirus; AP-1: Activator protein-1; EMSA: electrophoretic mobility shift assay; PARP-1: Poly (ADP-ribose) - polymerase-1; MTT: 3-(4, 5dimethylthiazol-2-yl)-2; 5-diphenyltetrazolium bromide; FACS: fluorescenceactivated cell sorting.

\section{Acknowledgements}

This work was supported by the funds from the Department of Biotechnology (DBT) and Indian Council of Medical Research (ICMR), Government of India (to B.C.D).

\section{Author details}

'Division of Molecular Oncology, Institute of Cytology and Preventive Oncology (Indian Council of Medical Research), 1-7, Sector-39, Noida, Gautam Budh Nagar - 201301 India. ${ }^{2}$ Department of Biosciences, Faculty of Natural Sciences, Jamia Millia Islamia, New Delhi -110025, India. ${ }^{3}$ Dr. B.R Ambedkar Centre for Biomedical Research, University of Delhi (North Campus), Delhi110007, India.

\section{Authors' contributions}

SM designed, performed experiments, analyzed data, and prepared the manuscript; ACB performed the experimental design, analyzed the data, drafted and wrote the manuscript; SS analyzed the data and helped in manuscript preparation; AT performed experiments of Flow cytometry; SAH reviewed the manuscript; and BCD initiated and planned the project, directed the whole study and revised the manuscript critically. All the authors read and proved the final manuscript.

\section{Competing interests}

The authors declare that they have no competing interests.

Received: 10 August 2010 Accepted: 15 April 2011

Published: 15 April 2011

\section{References}

1. Parkin DM: The global health burden of infection-associated cancers in the year 2002. Int J Cancer 2006, 118:3030-3044.

2. Durst M, Gissmann L, Ikenberg H, zur Hausen $H$ : A papillomavirus DNA from a cervical carcinoma and its prevalence in cancer biopsy samples from different geographic regions. Proc Natl Acad Sci USA 1983, 80:3812-3815.

3. Scheffner M, Werness BA, Huibregtse JM, Levine AJ, Howley PM: The E6 oncoprotein encoded by human papillomavirus types 16 and 18 promotes the degradation of p53. Cell 1990, 63:1129-1136.

4. Butz K, Hoppe-Seyler F: Transcriptional control of human papillomavirus (HPV) oncogene expression: composition of the HPV type 18 upstream regulatory region. J Virol 1993, 67:6476-6486.
5. Milde-Langosch $\mathrm{K}$ : The Fos family of transcription factors and their role in tumourigenesis. Eur J Cancer 2005, 41:2449-2461.

6. Prusty BK, Das BC: Constitutive activation of transcription factor AP-1 in cervical cancer and suppression of human papillomavirus (HPV) transcription and AP-1 activity in HeLa cells by curcumin. Int J Cancer 2005, 113:951-960.

7. Bharti AC, Shukla S, Mahata S, Hedau S, Das BC: Anti-human papillomavirus therapeutics: facts \& future. Indian J Med Res 2009, 130:296-310.

8. Gibbs PJ, Seddon KR: The British Library Studies in Conservation Science Toronto: University of Toronto Press Inc; 1998.

9. Imanshahidi $\mathrm{M}$, Hosseinzadeh $\mathrm{H}$ : Pharmacological and therapeutic effects of Berberis vulgaris and its active constituent, berberine. Phytother Res 2008, 22:999-1012.

10. Satyavathi GV, Gupta AK, Tandon N: Medicinal Plants of India New Delhi: Indian Council of Medical Research; 1987.

11. Sun $Y$, Xun $K$, Wang $Y$, Chen $X$ : A systematic review of the anticancer properties of berberine, a natural product from Chinese herbs. Anticancer Drugs 2009, 20:757-769.

12. Lin CC, Lin SY, Chung JG, Lin JP, Chen GW, Kao ST: Down-regulation of cyclin B1 and up-regulation of Wee1 by berberine promotes entry of leukemia cells into the G2/M-phase of the cell cycle. Anticancer Res 2006, 26:1097-1104.

13. Letasiova S, Jantova S, Cipak L, Muckova M: Berberine-antiproliferative activity in vitro and induction of apoptosis/necrosis of the U937 and B16 cells. Cancer Lett 2006, 239:254-262.

14. Mantena SK, Sharma SD, Katiyar SK: Berberine inhibits growth, induces G1 arrest and apoptosis in human epidermoid carcinoma A431 cells by regulating $\mathrm{Cdki-Cdk-cyclin} \mathrm{cascade,} \mathrm{disruption} \mathrm{of} \mathrm{mitochondrial}$ membrane potential and cleavage of caspase 3 and PARP. Carcinogenesis 2006, 27:2018-2027.

15. Hwang JM, Kuo HC, Tseng TH, Liu JY, Chu CY: Berberine induces apoptosis through a mitochondria/caspases pathway in human hepatoma cells. Arch Toxicol 2006, 80:62-73.

16. Kuo CL, Chi CW, Liu TY: The anti-inflammatory potential of berberine in vitro and in vivo. Cancer Lett 2004, 203:127-137.

17. Eom KS, Hong JM, Youn MJ, So HS, Park R, Kim JM, Kim TY: Berberine induces G1 arrest and apoptosis in human glioblastoma T98G cells through mitochondrial/caspases pathway. Biol Pharm Bull 2008, 31:558-562.

18. Peng PL, Hsieh YS, Wang CJ, Hsu JL, Chou FP: Inhibitory effect of berberine on the invasion of human lung cancer cells via decreased productions of urokinase-plasminogen activator and matrix metalloproteinase-2. Toxicol Appl Pharmacol 2006, 214:8-15.

19. Mantena SK, Sharma SD, Katiyar SK: Berberine, a natural product, induces G1-phase cell cycle arrest and caspase-3-dependent apoptosis in human prostate carcinoma cells. Mol Cancer Ther 2006, 5:296-308.

20. Lin JP, Yang JS, Lee JH, Hsieh WT, Chung JG: Berberine induces cell cycle arrest and apoptosis in human gastric carcinoma SNU-5 cell line. World J Gastroenterol 2006, 12:21-28.

21. Katiyar SK, Meeran SM, Katiyar N, Akhtar S: p53 cooperates berberineinduced growth inhibition and apoptosis of non-small cell human lung cancer cells in vitro and tumor xenograft growth in vivo. Mol Carcinog 2008, 48:24-37.

22. Anis KV, Rajeshkumar NV, Kuttan R: Inhibition of chemical carcinogenesis by berberine in rats and mice. J Pharm Pharmacol 2001, 53:763-768.

23. Nishino $H$, Kitagawa $K$, Fujiki $H$, Iwashima A: Berberine sulfate inhibits tumor-promoting activity of teleocidin in two-stage carcinogenesis on mouse skin. Oncology 1986, 43:131-134.

24. Kim S, Choi JH, Kim JB, Nam SJ, Yang JH, Kim JH, Lee JE: Berberine suppresses TNF-alpha-induced MMP-9 and cell invasion through inhibition of AP-1 activity in MDA-MB-231 human breast cancer cells. Molecules 2008, 13:2975-2985.

25. Yount G, Qian Y, Moore D, Basila D, West J, Aldape K, Arvold N, Shalev N, Haas-Kogan D: Berberine sensitizes human glioma cells, but not normal glial cells, to ionizing radiation in vitro. J Exp Ther Oncol 2004, 4:137-143.

26. Lin JP, Yang JS, Chang NW, Chiu TH, Su CC, Lu KW, Ho YT, Yeh CC, Mei D, Lin HJ, Chung JG: GADD153 mediates berberine-induced apoptosis in human cervical cancer Ca ski cells. Anticancer Res 2007, 27:3379-3386.

27. Bharti AC, Panigrahi A, Sharma PK, Gupta N, Kumar R, Shukla S, Bhowmik DM, Agarwal SK, Guleria S, Mehra NK: Clinical relevance of 
curcumin-induced immunosuppression in living-related donor renal transplant: an in vitro analysis. Exp Clin Transplant 2010, 8:161-171.

28. Rosl F, Das BC, Lengert M, Geletneky K, zur Hausen H: Antioxidant-induced changes of the AP-1 transcription complex are paralleled by a selective suppression of human papillomavirus transcription. J Virol 1997, 71:362-370.

29. Lee W, Mitchell P, Tjian R: Purified transcription factor AP-1 interacts with TPA-inducible enhancer elements. Cell 1987, 49:741-752.

30. Scheidereit C, Cromlish JA, Gerster T, Kawakami K, Balmaceda CG, Currie RA Roeder RG: A human lymphoid-specific transcription factor that activates immunoglobulin genes is a homoeobox protein. Nature 1988, 336:551-557.

31. Kadonaga JT, Courey AJ, Ladika J, Tjian R: Distinct regions of Sp1 modulate DNA binding and transcriptional activation. Science 1988, 242:1566-1570.

32. Thierry F, Spyrou G, Yaniv M, Howley P: Two AP1 sites binding JunB are essential for human papillomavirus type 18 transcription in keratinocytes. J Virol 1992, 66:3740-3748.

33. Parker JN, Zhao W, Askins KJ, Broker TR, Chow LT: Mutational analyses of differentiation-dependent human papillomavirus type 18 enhancer elements in epithelial raft cultures of neonatal foreskin keratinocytes. Cell Growth Differ 1997, 8:751-762.

34. Kyo S, Klumpp DJ, Inoue M, Kanaya T, Laimins LA: Expression of AP1 during cellular differentiation determines human papillomavirus E6/E7 expression in stratified epithelial cells. J Gen Virol 1997, 78(Pt 2):401-411.

35. Fukuda K, Hibiya Y, Mutoh M, Koshiji M, Akao S, Fujiwara H: Inhibition of activator protein 1 activity by berberine in human hepatoma cells. Planta Med 1999, 65:381-383.

36. Luo Y, Hao Y, Shi TP, Deng WW, Li N: Berberine inhibits cyclin D1 expression via suppressed binding of AP-1 transcription factors to CCND1 AP-1 motif. Acta Pharmacol Sin 2008, 29:628-633.

37. Soto $U$, Das BC, Lengert M, Finzer P, zur Hausen H, Rosl F: Conversion of HPV 18 positive non-tumorigenic HeLa-fibroblast hybrids to invasive growth involves loss of TNF-alpha mediated repression of viral transcription and modification of the AP-1 transcription complex. Oncogene 1999, 18:3187-3198.

38. Cho BJ, Im EK, Kwon JH, Lee KH, Shin HJ, Oh J, Kang SM, Chung JH, Jang Y Berberine inhibits the production of lysophosphatidylcholine-induced reactive oxygen species and the ERK1/2 pathway in vascular smooth muscle cells. Mol Cells 2005, 20:429-434.

39. Liang KW, Ting CT, Yin SC, Chen YT, Lin SJ, Liao JK, Hsu SL: Berberine suppresses MEK/ERK-dependent Egr-1 signaling pathway and inhibits vascular smooth muscle cell regrowth after in vitro mechanical injury. Biochem Pharmacol 2006, 71:806-817.

40. Cavigelli M, Dolfi F, Claret FX, Karin M: Induction of c-fos expression through JNK-mediated TCF/Elk-1 phosphorylation. Embo J 1995, 14:5957-5964.

41. Bakiri L, Lallemand D, Bossy-Wetzel E, Yaniv M: Cell cycle-dependent variations in c-Jun and JunB phosphorylation: a role in the control of cyclin D1 expression. Embo J 2000, 19:2056-2068.

42. Passegue E, Wagner EF: JunB suppresses cell proliferation by transcriptional activation of p16(INK4a) expression. Embo J 2000, 19:2969-2979.

43. Yang-Yen HF, Chambard JC, Sun YL, Smeal T, Schmidt TJ, Drouin J, Karin M: Transcriptional interference between c-Jun and the glucocorticoid receptor: mutual inhibition of DNA binding due to direct protein-protein interaction. Cell 1990, 62:1205-1215.

44. Chong T, Chan WK, Bernard HU: Transcriptional activation of human papillomavirus 16 by nuclear factor I, AP1, steroid receptors and a possibly novel transcription factor, PVF: a model for the composition of genital papillomavirus enhancers. Nucleic Acids Res 1990, 18:465-470.

45. Veldman T, Horikawa I, Barrett JC, Schlegel R: Transcriptional activation of the telomerase hTERT gene by human papillomavirus type 16 E6 oncoprotein. J Virol 2001, 75:4467-4472.

46. Kailash U, Soundararajan CC, Lakshmy R, Arora R, Vivekanandhan S, Das BC: Telomerase activity as an adjunct to high-risk human papillomavirus types 16 and 18 and cytology screening in cervical cancer. Br J Cancer 2006, 95:1250-1257.

47. Wu HL, Hsu CY, Liu WH, Yung BY: Berberine-induced apoptosis of human leukemia HL-60 cells is associated with down-regulation of
nucleophosmin/B23 and telomerase activity. Int J Cancer 1999, 81:923-929.

48. Serafim TL, Oliveira PJ, Sardao VA, Perkins E, Parke D, Holy J: Different concentrations of berberine result in distinct cellular localization patterns and cell cycle effects in a melanoma cell line. Cancer Chemother Pharmacol 2008, 61:1007-1018.

49. Jantova S, Cipak L, Cernakova M, Kost'alova D: Effect of berberine on proliferation, cell cycle and apoptosis in HeLa and L1210 cells. J Pharm Pharmacol 2003, 55:1143-1149.

50. Youn MJ, So HS, Cho HJ, Kim HJ, Kim Y, Lee JH, Sohn JS, Kim YK, Chung SY, Park R: Berberine, a natural product, combined with cisplatin enhanced apoptosis through a mitochondria/caspase-mediated pathway in HeLa cells. Biol Pharm Bull 2008, 31:789-795.

51. Shitan N, Tanaka M, Terai K, Ueda K, Yazaki K: Human MDR1 and MRP1 recognize berberine as their transport substrate. Biosci Biotechnol Biochem 2007, 71:242-245.

52. Stermitz FR, Lorenz P, Tawara JN, Zenewicz LA, Lewis K: Synergy in a medicinal plant: antimicrobial action of berberine potentiated by $5^{\prime}$ methoxyhydnocarpin, a multidrug pump inhibitor. Proc Natl Acad Sci USA 2000, 97:1433-1437.

53. Gong GQ, Zong ZX, Song YM: Spectrofluorometric determination of DNA and RNA with berberine. Spectrochim Acta A Mol Biomol Spectrosc 1999, 55A:1903-1907.

54. Hail N Jr: Mitochondria: A novel target for the chemoprevention of cancer. Apoptosis 2005, 10:687-705.

55. Ho YT, Lu CC, Yang JS, Chiang JH, Li TC, Ip SW, Hsia TC, Liao CL, Lin JG, Wood WG, Chung JG: Berberine induced apoptosis via promoting the expression of caspase-8, -9 and -3 , apoptosis-inducing factor and endonuclease $\mathrm{G}$ in SCC-4 human tongue squamous carcinoma cancer cells. Anticancer Res 2009, 29:4063-4070.

56. Choi MS, Oh JH, Kim SM, Jung HY, Yoo HS, Lee YM, Moon DC, Han SB, Hong JT: Berberine inhibits p53-dependent cell growth through induction of apoptosis of prostate cancer cells. Int J Oncol 2009, 34:1221-1230.

57. Lin CC, Yang JS, Chen JT, Fan S, Yu FS, Yang JL, Lu CC, Kao MC, Huang AC, Lu HF, Chung JG: Berberine induces apoptosis in human HSC-3 oral cancer cells via simultaneous activation of the death receptor-mediated and mitochondrial pathway. Anticancer Res 2007, 27:3371-3378.

58. Tang F, Wang D, Duan C, Huang D, Wu Y, Chen Y, Wang W, Xie C, Meng J, Wang $L$, et al: Berberine inhibits metastasis of nasopharyngeal carcinoma 5-8F cells by targeting Rho kinase-mediated Ezrin phosphorylation at threonine 567. J Biol Chem 2009, 284:27456-27466.

59. Lin CC, Kao ST, Chen GW, Ho HC, Chung JG: Apoptosis of human leukemia HL-60 cells and murine leukemia WEHI-3 cells induced by berberine through the activation of caspase-3. Anticancer Res 2006, 26:227-242.

60. Lin HL, Liu TY, Lui WY, Chi CW: Up-regulation of multidrug resistance transporter expression by berberine in human and murine hepatoma cells. Cancer 1999, 85:1937-1942.

61. Tan YL, Goh D, Ong ES: Investigation of differentially expressed proteins due to the inhibitory effects of berberine in human liver cancer cell line HepG2. Mol Biosyst 2006, 2:250-258.

62. Halimani M, Chandran SP, Kashyap S, Jadhav VM, Prasad BL, Hotha S, Maiti S: Dendritic effect of ligand-coated nanoparticles: enhanced apoptotic activity of silica-berberine nanoconjugates. Langmuir 2009, 25:2339-2347.

63. Lin TH, Kuo HC, Chou FP, Lu FJ: Berberine enhances inhibition of glioma tumor cell migration and invasiveness mediated by arsenic trioxide. BMC Cancer 2008, 8:58.

64. Dvorak Z, Vrzal R, Maurel P, Ulrichova J: Differential effects of selected natural compounds with anti-inflammatory activity on the glucocorticoid receptor and NF-kappaB in HeLa cells. Chem Biol Interact 2006, 159:117-128.

doi:10.1186/1476-4598-10-39

Cite this article as: Mahata et al:: Berberine modulates AP-1 activity to suppress HPV transcription and downstream signaling to induce growth arrest and apoptosis in cervical cancer cells. Molecular Cancer 2011 10:39. 